\title{
Optimal Design Of Renewable Energy System using Genetic Algorithm Case Study In Parangtritis
}

\author{
SRI UTAMI \\ Departement of Energy Conversion Engineering Bandung State Polytechnic \\ Email : sri.utami@polban.ac.id
}

\begin{abstract}
ABSTRAK
Andil pariwisata terhadap perkembangan regional sangat besar begitu juga andilnya terhadap permasalahan lingkungan. Untuk mengurangi aspek negatif terhadap lingkungan serta meningkatkan penghematan, sistem energi terbarukan menempati prioritas penting dalam bidang pariwisata. Konfigurasi optimal sistem energi terbarukan direncanakan menggunakan Algoritma Genetika. Penelitian ini dilakukan untuk mengoptimasi sistem energi terbarukan di Parangtritis, Kretek, Bantul, Jawa Tengah. Sistem yang dirancang terdiri dari sel surya dan turbin angin, sedangkan sistem penyimpanannya menggunakan baterai dan fuel cell. Algoritma ini meminimisasi fungsi objektif biaya total yang terdiri dari biaya investasi, biaya penggantian serta biaya operasi dan perawatan. Kehandalan sistem dievaluasi menggunakan indeks Equivalent Loss Factor $(\boldsymbol{E} \boldsymbol{L F})$. Indeks ini memberikan informasi jumlah energi yang tidak dapat dipasok oleh sistem energi terbarukan. Hasil simulasi memperlihatkan jumlah optimal sistem energi terbarukan dicapai dengan jumlah sel surya sebanyak 3, baterai 48, turbin angin sebanyak 36, elektroliser sebanyak 3, tangki hidrogen 2 dan fuel cell sebanyak 8. Nilai ELF yang digunakan dalam penelitian ini adalah 0.01 .
\end{abstract}

\begin{abstract}
Tourism has a massive contribution to regional development and shares environmental issues. Reducing reliances on fossil fuel, it is not still adequating energy consumption yet to cause development of renewable energy in crucial position for tourism desicition. An optimal configuration of renewable energy system was planned by Genetic Algorithm in this work. This research conducted to optimize renewable energy system in Parangtritis, Kretek, Bantul Central Java. The system consisted of solar cells and wind turbines, and the batteries and fuel cells were as storage system. The algorithm minimize objective function of total cost consisted of investment, replacement as well as operating and maintenance costs. A reability evaluation of the system was given by Equivalent Loss Factor (ELF). This index inform an insufficient energy in the systems. The simulation showed an optimum size of the system, achieved by size of PV, battery, wind turbine, electrolizer, hidrogen tank and fuel cell were 3, 48, 36, 3, 2,8 respectively. The ELF used in this simulation was 0.01 .
\end{abstract}

Keywords: fossil fuel, renewable energy, tourism, Equivalent Lost Factor 


\section{INTRODUCTION}

Tourism is one of important economic driver of region. At the same time, it still depended on fosil energy sources, that are very vulnerable to fuel availability as well as the rise and fall of oil costs, to meet energy needs. Integration of renewable energy, using appropriate combination, is able to compensate the weakness of one source using advantages of the other source.

Variation of several combinations, both renewable energy sources and storage media, and system cost optimization have been done by several researchers. (Yang et al, 2008) proposed optimization of hybrid system of wind turbine, solar cell and battery banks using loss of power supply probability (LPSP) method. In (Hakimi and Tafreshi, 2009) performed an optimization in Kahnouj in the southeastern region of Iran using particle swarm. In this research, (Hakimi and Tafreshi, 2009) assumed stand-alone system consisting fuel cells, some wind units, some electrolyzers, a reformer, an anaerobic reactor and some hydrogen tanks. An optimal cost for stand-alone hybrid renewable energy system also has been found by (Tolooi et al, 2014) using the evolutionary algorithm. This algorithm was based on a collective intelligence (gravitational search algorithm). Furthermore, (Tolooi et al, 2014) also found the optimal value for hydrid system using particle swarm optimization as comparison.

The proposed method in this study was the genetic algorithm. This algorithm was widely used because of its ability to find an optimal solution to an optimization problem. In this study, the genetic algorithm was used to optimize the design of renewable energy systems for the area of Parangtritis consisting of solar cells, wind turbines, batteries and fuel cells. The design of optimal system minimized the net present cost (NPC), including the cost of the investment (capital cost), the cost of the replacement (replacement cost), and the operating and maintenance costs (operation and maintenance cost).

\subsection{Hybrid system}

The hybrid system combines two or more sources of energy, from renewable or conventional energy sources, with storage media. This hybrid system design can be different following the renewable energy sources available locally to meet the load requirements. Parangtritis, located in Kretek, Bantul, Central Java, has a high potential of hybrid renewable energy system considering the geographical location as well as the intensity of the sun and wind velocity.

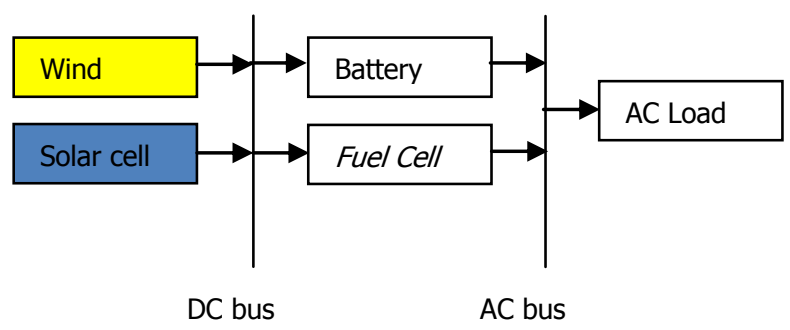

Figure 1. Configuration of renewable energy system

The integration of several sources and different media used in this work is ilustrated in Figure 1 . The renewable energy sources were wind turbine and solar cell. As the storage media, battery and fuel cell were used. 


\subsection{Renewable Energy Components}

To predict the performance of the system, first step was to model each of individual component of the system. After modeling,every component could be combined for further evaluation to meet the load requirements.

\subsubsection{Photovoltaic}

Solar panel power output is influenced by insulation condition. (Suryoatmojo, 2010) and (Penangsang et al, 2013) used Equation (1) for modeling the solar cells

$$
P_{P V(t)}=\eta \times A p \times N_{P V} \times E(t)
$$

Where $\eta, A_{p}, N_{p V}$ and $E(t)$ were efisiensi energy conversion(\%), the area of the solar panel $\left(\mathrm{m}^{2}\right)$, the number of photovoltaic panels, and the data solar insulation per hour $\left(\mathrm{W} / \mathrm{m}^{2}\right)$ respectively.

\subsubsection{Wind Turbine}

Determination of wind turbine modeling is a crucial for the output power. (Yusuf, 2012) used a mathematic model of Equation (2)

$$
\boldsymbol{P}_{\text {wg,t }}=\left\{\begin{array}{cc}
\mathbf{0} & v_{t}<v_{\text {cutin }}, v_{t}>v_{\text {cutout }} \\
\boldsymbol{P}_{\text {max }}\left(\frac{v_{t}-v_{\text {cutin }}}{v_{\text {rated }}-v_{\text {cutin }}}\right) & v_{\text {cutin }} \leq v_{t} \leq v_{\text {rated }} \\
\boldsymbol{p}_{\text {max }}+\left(\frac{p_{\text {furl }}-\boldsymbol{p}_{\text {max }}}{v_{\text {cutout }}-v_{\text {rated }}}\right) \cdot\left(v_{t}-v_{\text {rated }}\right) & v_{\text {rated }}<v_{t} \leq v_{\text {cutout }}
\end{array}\right.
$$

Where $v_{t}, v_{\text {cutin }}, v_{\text {cutout, }} v_{\text {rated }}$ werethe wind speed in one step a time,the value when the cut-in wind speed, the value of the current wind speed in cut out and the value of wind speed(rate) of the wind turbine $(\mathrm{m} / \mathrm{s})$ respectively. While $p_{\max }$ and $p_{\text {furl }}$ were the maximum output power and the power output at a speed ofcut-outs (kW) calculated after passing through the inverter respectively.

\subsection{Storage Components}

\subsubsection{Battery}

There were two required conditions to be considered related to charging and discharge condition for the battery at the time t. While battery charging, (Suryoatmojo, 2010) it is used Equation (3)

$$
\mathrm{C}_{\text {bat }(\mathrm{t})}=\mathrm{C}_{\text {bat }(\mathrm{t}-1)}+\left(\mathrm{P}_{\text {ren }(\mathrm{t})}-\mathrm{P}_{\text {load }(\mathrm{t})}\right)
$$

And for discharging, Equation (4) is used,

$$
C_{\text {bat }(t)}=C_{\text {bat }(t-1)}-\left(P_{\text {load }(t)}-P_{\text {ren }(t)}\right)
$$

where $C_{b a t(t)}$ and $C_{b a t(t-1)}$ are the capacity ofthe battery during the time $t$, and the capacity of the battery at previous time. 


\subsubsection{Fuel Cell}

The fuel cell system consisted of electrolizer, hydrogen tank and fuel cell. A mathematical formula is as below:

\subsubsection{Electrolizer}

The power generated from the electrolysis process was using Equation (5)(Yusuf, 2012)

$$
\boldsymbol{P}_{e l, t}=\left(\boldsymbol{P}_{\text {ren }, t}-\boldsymbol{P}_{\text {load }, t}\right)
$$

Where $P_{\text {el,t}}$ was the electrical power delivered to the electrolyzer from renewable system

\subsubsection{Hydrogen Tank}

Energy flow into the hydrogen tank could be represented by the Equation(6)(Yusuf, 2012)

$$
\mathrm{C}_{\mathrm{tank}, \mathrm{t}}=\mathrm{C}_{\mathrm{tank},(\mathrm{t}-1)}+\mathrm{P}_{\mathrm{el}, \mathrm{t}}
$$

Where $\mathrm{C}_{\text {tanks, }}$ tand $\mathrm{C}_{\mathrm{tanks}}(\mathrm{t}-1)$ were the total amountof energy in the hydrogen tank when $\mathrm{t}$ and the previous time(t-1) respectively.

\subsubsection{Fuel Cell}

The output from the fuel cell was proportional to the input power of hydrogen calculated by Equation (7)(Yusuf, 2012)

$$
P_{f c, t}=\left(P_{\text {load }, t}-P_{\text {ren }, t}\right)
$$

\subsection{Genetic Algorithm}

The concept of genetic algorithm is different from the Traditional search and optimization methods in the engineering problems. In this algorithm, basic principle of genetic processes in biology was imitated in search process.This technique was introduced to search the optimal solution based on natural selection (Suryoatmojo,2010).

In the genetic algorithm, like other algorithms in search optimization, it was required defining optimization variables and function costs.Like another algorithm, the value of convergence wouldl be tested.

Main used components in the genetic algorithmisas follows(Bramantyo, 2006):

1. Coding Scheme

2. Population

3. Naturalselection

4. Selection

5. Mating

6. Mutation

7. The next generation

The cycles of genetic algorithm was depicted in Figure 2. 


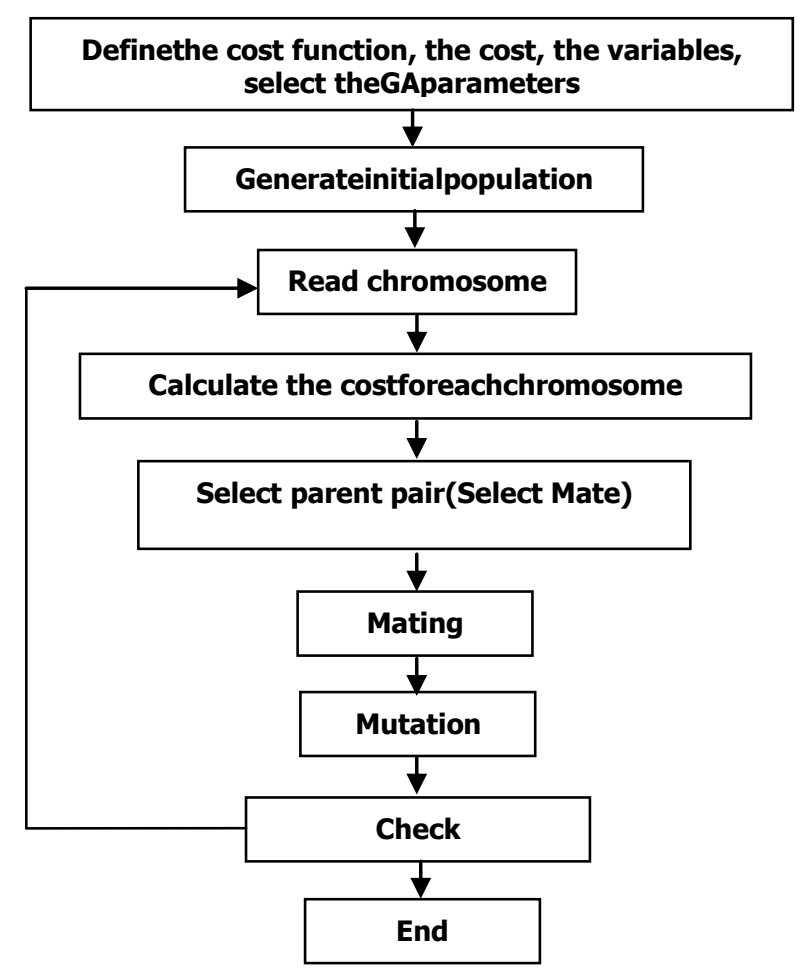

Figure 2. Flowchart of genetic algorithm

The algorithm was commenced by defining the function of costs, variables and Genetic Algorithm parameters as shown in Figure (2). Next step was to determine number of population that would be used. This population consisted of a group of chromosome known as gen. Value of the gen could be numeric, biner, character or symbol. Selection also was known as matchmaker. In this step, two chromosome were chosen from the survive one to produce children (offspring). Mating was a formation process of offspring from elected parents from the pevious process. Next process was mutation carried by replacing randomly selected gen with new value. Last step was to test convergence of the algorithm.

\subsection{Problem Formulations}

\subsubsection{Objective Function (Economic Modelling Based on Net Present Cost (NPC))}

The cost component was calculated using the Net Present Cost (NPC) consisting of cost ofthe investment (capital cost replacement cost, and operating and maintenance costs. This cost would be calculated by the value of money at this time.

This method can be described by Equation (8):

$$
\mathrm{NPC}=\mathrm{CC}_{\mathrm{i}}+\mathrm{RC}_{\mathrm{i}} \cdot \mathrm{K}_{\mathrm{i}}+\mathrm{MC}_{\mathrm{i}} \cdot \mathbf{P W A}(\mathrm{ir}, \mathrm{R})
$$

Where $\mathrm{CC}_{\mathrm{i}}$ is the investment cost (\$ / unit). $\mathrm{RC}$ is The replacement cost ( $\$$ / unit). While $M C_{i}$ is operating and maintenance costs (\$/unit-year). Replacement cost $\mathrm{RC}_{\mathrm{i}}$ will be multiplied by $\mathrm{K}_{\mathrm{i}}$. A conversion factor value for money at a certain moment in the future to the current time because the calculation of the cost was calculated by the value of money at this time. While the operating and maintenance costs will be multiplied by PWA (annual payment present worth) that is used to convert annual cost of operating and maintaining backwards today. 


\subsubsection{Constrain}

Some restrictions which used to optimize objective function in renewable generation systems areas follows:

(1) The balance of power system

$$
\sum\left(\mathbf{P}_{\mathrm{t}, \mathrm{t}} \geq \mathbf{P}_{\text {load, } \mathrm{t}}-\mathbf{Q}_{\mathrm{t}}\right)
$$

(2) Index of system reliability

$$
E[E L F] \leq E L F_{\max }
$$

(3) Number of units and equipment

$$
\mathbf{N}_{\mathrm{wt}}, \mathbf{N}_{\mathrm{pv}}, \mathbf{N}_{\mathrm{bat}}, \mathrm{N}_{\mathrm{el}}, \mathbf{N}_{\text {tank }}, \mathbf{N}_{\mathrm{fc}} \geq \mathbf{0}
$$

(4) Boundary of batteries

$$
C_{b t_{\text {min }}} \leq C_{b a t}(t) \leq C_{b a t_{\text {max }}}
$$

(5) Limitation of hidrogen tank

$$
\mathrm{C}_{\mathrm{tank}_{\text {max }}} \leq \mathrm{C}_{\text {tank }}(\mathrm{t}) \leq \mathrm{C}_{\mathrm{tank}_{\text {max }}}
$$

\subsubsection{Equivalent Loss Factor (ELF)}

The equivalent Loss Factor willcompare to each other amount the energy produced to the load requirementsin one year. (Bashir and Sadeh ,2012) and (Garcia and Weisser, 2006) calculated ELF using equation(14):

$$
\mathrm{ELF}=\frac{1}{H} \sum_{i=1}^{H} \frac{Q(i)}{D(i)}
$$

$\mathrm{H}$ was the total numbe of time steps (8760), Q(i) was the total load that could not be met and $\mathrm{D}(\mathrm{i})$ was the total load demand per time step.

\subsection{Operational Strategy}

The operational strategy used in this renewable energy system was depicted as below:

1. When the total load demand load was smaller than the produced output renewable generation systems, the remaining energy would be stored into the battery

2. When the battery capacity was full (and there was still residual energy) charging, it would be continued to the fuel cell

3. When the fuel cell hadt he maximum capacity, the excess energy would be discharged into dump load

4. When the load demand was greater than the power that could be supplied by the renewable generation, the shortage would be supplied by the battery

5. When the load demand remains greater, despite being supplied by the battery, the energy shortage would be fulfilled by the fuel cell 


\section{IMPLEMENTATION}

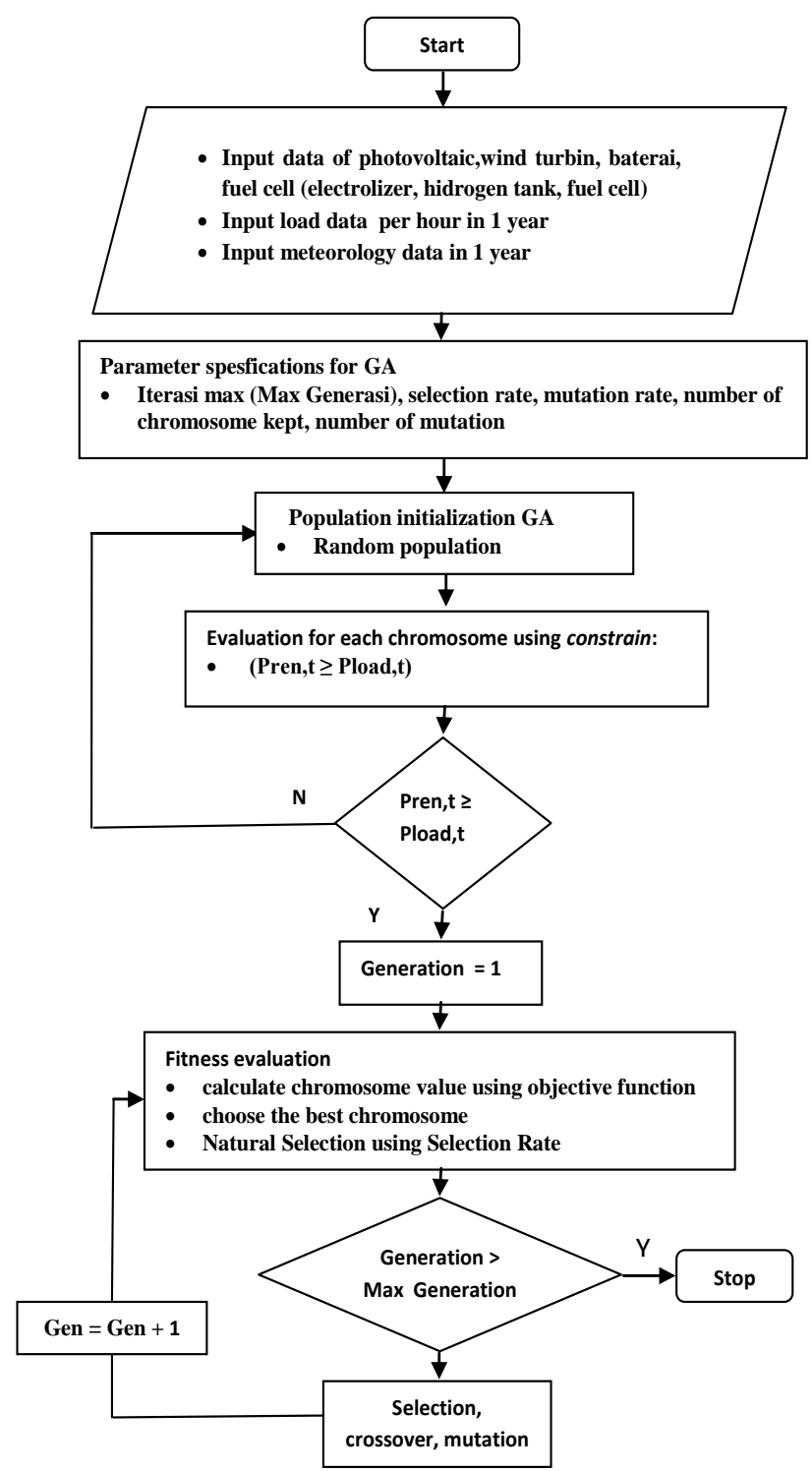

Figure 3. Implementation of Genetic Algorithm

The optimum system consisted of solar cells, wind turbines and storage media (electrolizer, hidrogen tank and fuel cell). Simulation was done for 8760 times. The project time was assumed for 20 years. The storage media were assumed full when the system established. Flowchart for the optimum configuration of the renewable energy systems with the proposed algorithm is shown in Figure 3.

\subsection{Simulation}

Parangtritis was used for the casestudy in this research to design the hybrid system simulation. The daily load demand characteristic in Parangtritis is shown in Figure 4.This simulation used data per hour for one day and repeated for one year or 8760hours. A time period of this project was 20 years. The specification of PV panel, wind turbine, battery and fuel cell used in this study can be seenin Table 1, 2, 3and 4. The parameters of GA used in this study are shown in Table 5. 
Optimal Design of Reneweble Energy Sytem for Tourism Destination ParangtritisUsing Genetic Algorithm

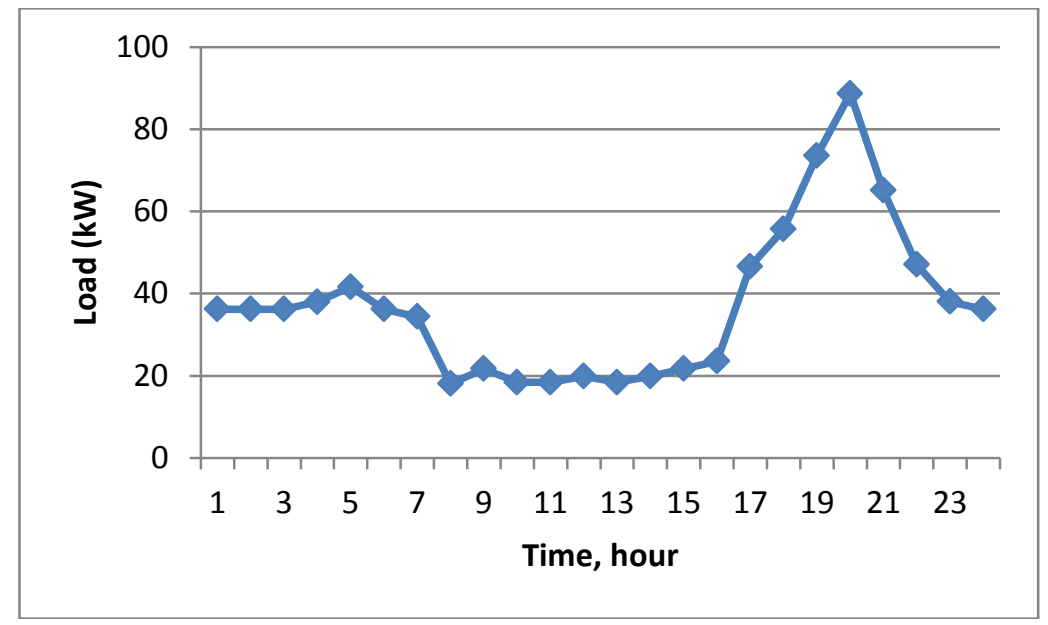

Figure 4. Daily load profile

The used solar panels were the solar cell modules of Canadian Solar CS6P-240p. Table 1 shown specifications for the modules for each solar cell array that consisted of four modules to produce power $0.96 \mathrm{~kW}$.

Table 1. Specifications solar cell module Canadian Solar CS6P-240p (at standard test conditions Irradiance $1000 \mathrm{~W} / \mathrm{m2}$, AM1.5 spectrum and solar cell temperature $25^{\circ} \mathrm{C}$ )

(K. M. Iromi, 2013)

\begin{tabular}{|l|c|r|}
\hline Nominal MaximumPower & $P_{m p p}$ & $240 \mathrm{~W}$ \\
\hline Optimum operating voltage & $V_{m p p}$ & $29.9 \mathrm{~V}$ \\
\hline Optimum operating current & $I_{m p p}$ & $8.03 \mathrm{~A}$ \\
\hline Open circuit voltage & $V_{o c}$ & $37.0 \mathrm{~V}$ \\
\hline Short circuit current & $I_{s c}$ & $8.59 \mathrm{~A}$ \\
\hline Module efficiency & $\eta$ & $14.92 \%$ \\
\hline Temperature coefficient at Pmpp & & $-0.43 \%{ }^{\circ} \mathrm{C}^{-1}$ \\
\hline $\begin{array}{l}\text { Nominal Operating Cell Temperature } \\
\text { (NOCT) }\end{array}$ & & $45 \pm 2^{\circ} \mathrm{C}$ \\
\hline Capital Cost & $\mathrm{CC}$ & $7000(\$ /$ unit $)$ \\
\hline Replacement Cost & $\mathrm{RC}$ & 6000 (\$) unit) \\
\hline Maintenance Cost & $\mathrm{MC}$ & $20(\$ /$ unit $)$ \\
\hline
\end{tabular}

BWC Excel-R / 48 artificial Bergey Wind Power's used in this research. The turbine has rated power capacity $7.5 \mathrm{~kW}$ and output voltage 48 volts (dc). The specifications of this wind turbine were shown in Table 2.

Table 2 Specifications of Wind Turbines (A Navaeefard et al, 2010),(Bashir and Sadeh ,2012), (Nowdeh et al, 2010).

\begin{tabular}{|l|c|r|}
\hline Cut-in Speed & $\mathrm{v}_{\text {cutin }}$ & $3(\mathrm{~m} / \mathrm{s})$ \\
\hline Cut-out Speed & $\mathrm{v}_{\text {cutout }}$ & $25(\mathrm{~m} / \mathrm{s})$ \\
\hline Rated Speed & $\mathrm{c}_{\text {rated }}$ & $15(\mathrm{~m} / \mathrm{s})$ \\
\hline Maximum Output Power & $\mathrm{p}_{\max }$ & $8,1(\mathrm{~kW})$ \\
\hline Maximum Output Power Cut-out & $\mathrm{p}_{\text {furl }}$ & $5,8(\mathrm{~kW})$ \\
\hline Capital Cost & CC & $16.400(\$ /$ Unit $)$ \\
\hline Replacement Cost & RC & $13.000(\$ /$ Unit $)$ \\
\hline Maintenance Cost & MC & $400(\$ /$ Unit-year $)$ \\
\hline
\end{tabular}


For this study the used battery was Surrette-6CS25P, and the assumed life of the battery was 10 years old and the depth of discharge was about $80 \%$. Specifications for the battery was shown in Table 3.

Table 3. Specifications of Battery Storage (M. Bashir, 2012)

\begin{tabular}{|l|c|r|}
\hline Battery Capacity & & $6,94(\mathrm{kWh})$ \\
\hline Charge Efficiency & $\eta_{\text {charge }}$ & 0,9 \\
\hline Discharge Efficiency & $\eta_{\text {discharge }}$ & 0,9 \\
\hline Time periode & & 10 (tahun) \\
\hline DOD & & 0,8 \\
\hline Capital Cost & CC & $1.250(\$ /$ Unit $)$ \\
\hline Replacement Cost & RC & 1.200 (\$/Unit) \\
\hline Maintenance Cost & MC & $20(\$ /$ Unit-year) \\
\hline
\end{tabular}

Table 4 shown specifications for used fuel cell in this research. The used fuel cell was assumed for 20 years.

Table 4. Fuel cell spesifications (http://hypertextbook.com)

\begin{tabular}{|l|r|r|}
\hline Capacity & & $0,5 \mathrm{kWh}$ \\
\hline Efficiency & $\eta_{f c}$ & 0,7 \\
\hline Time Period & & 20 (tahun) \\
\hline Capital Cost & CC & $3.000(\$ /$ Unit $)$ \\
\hline Replacement Cost & RC & $2.500(\$ /$ Unit $)$ \\
\hline Maintenance Cost & MC & $175(\$ /$ Unit-year $)$ \\
\hline
\end{tabular}

The used algorithm parameters were in Table 5 below. Table 5 shown the used population was 32. The parameters values were obtained from the experiment to achieve optimal configuration of the renewable energy system.

Table 5. Genetic Algorithms Parameters

\begin{tabular}{|l|l|}
\hline Population & 32 \\
\hline Mutation rate & 0.2 \\
\hline Crossover & One point crossover \\
\hline Iteration & 120 \\
\hline
\end{tabular}

\section{RESULT AND DISCUSSION}

The total cost of the system can be specified for each element in renewable generation systems as shown in Figure 5 . The investment costs for thebuiltsystem was $\$ 711,120$, while the cost of battery replacement, eleCtrolizer, hydrogen tank and the fuel cell for $\$ 29,484$. In this study, it was assumed the replacement battery as much as one, but not the other component replacements performed over the life of the project. The cost for operating and maintenance costs of the system was $\$ 57,970$ 
Optimal Design of Reneweble Energy Sytem for Tourism Destination ParangtritisUsing Genetic Algorithm

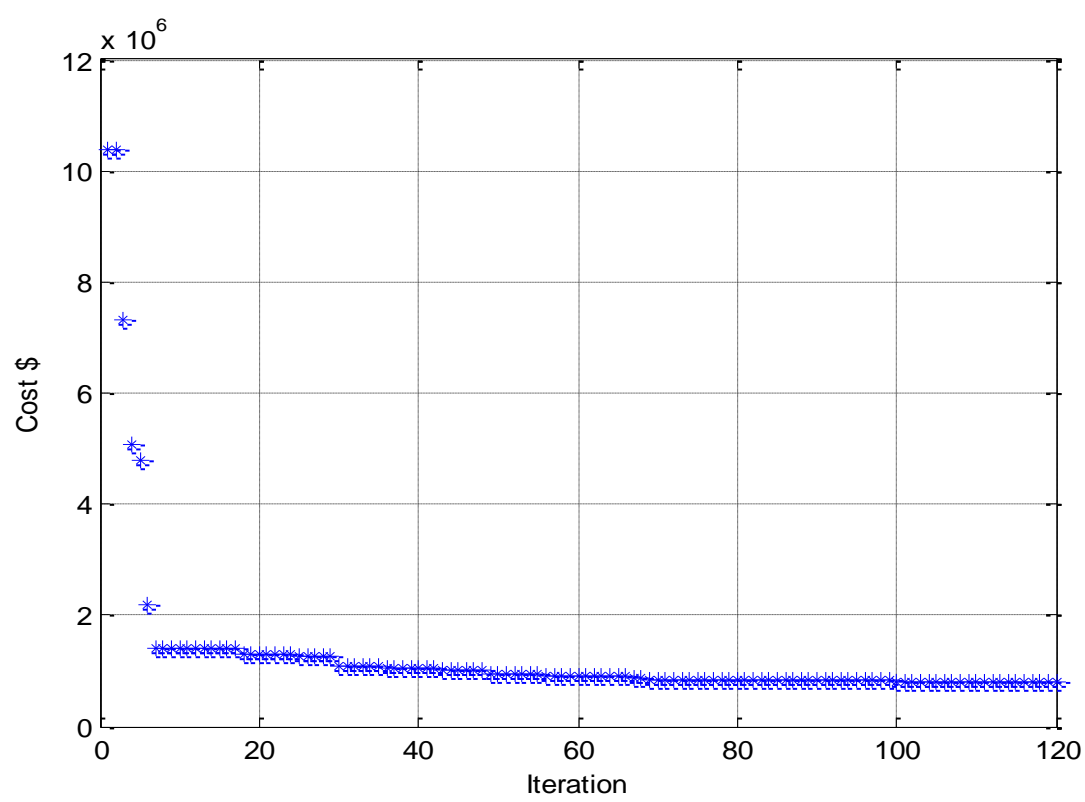

Figure 5.Iteration result

This simulation crossover rate used was one point crossover, while the probabilty mutation (mutation rate) was used 0.2. When the maximum number of iterations was reached, the optimal configuration was obtained. In the last iteration could be concluded that required cost for the this renewable energy system was $\$ 798,570$ for the system configuration as shown in Table 6.

Table 6.

\begin{tabular}{|l|l|l|}
\hline No & Components & Size \\
\hline 1 & Solar cell & 3 \\
\hline 2 & Batteries & 48 \\
\hline 3 & Wind turbine & 36 \\
\hline 4 & Electrolizer & 3 \\
\hline 5 & Tangki hidrogen & 2 \\
\hline 6 & Fuel cell & 8 \\
\hline
\end{tabular}

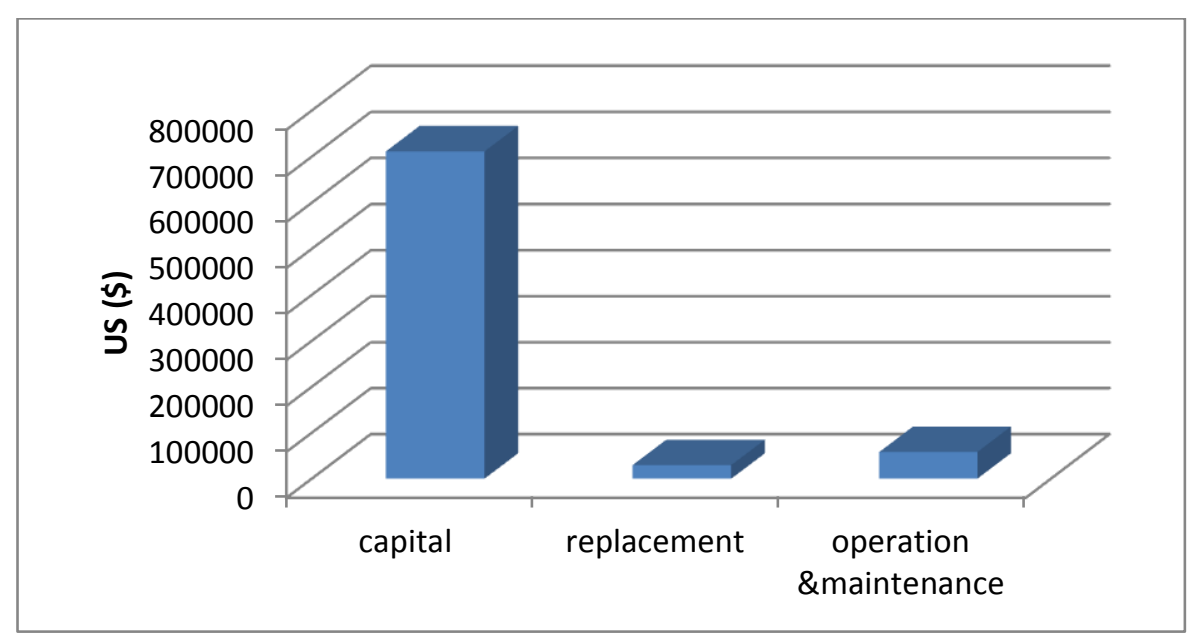

Figure 6. Cost for each system component 
The cost for each of componentis as in Figure 6 . The total cost of the system could be determined for each element in the renewable energy system as shown in Figure 6.The investment costs for the built system built was $\$ 711,120$ and the amount of cost for the battery replacement, the electrolizer, the hydrogen tank and the fuel cell was $\$ 29,484$. The battery replacement was carried out one time and there was not replacement for the other components. The operational and maintenance cost of the system was \$57970.

\section{CONCLUSION}

Optimal design of renewable energy hybrid systems consisting of solar cells, wind turbines, batteries and a fuel cell was simulated using genetic algorithms Parangtritis, Kretek, Bantul, Central Java. The results obtained could be explained as follow:

1 . The total of solar cell was 3 at cost $\$ 21660$

2. The total of battery was 48 at cost $\$ 10004$

3. The total of wind turbine was 36 at cost $\$ 6201$

4. The total of electrolizer was 3 at cost $\$ 10320$

5 . The total of hidrogen tank was 2 at cost $\$ 7050$

6. The total of fuel cell was 8 at cost $\$ 39400$

\section{REFERENCES}

A. Navaeefard, S.M.M. Tafreshi, M. Barzegari and A.J. Shahrood. (2010). Optimal Sizing of Distributed Energy Resources in Microgrid Considering Wind Energy Uncertainty with Respect to Reliability

Bashir,M and Sadeh, J. (2012). Size Optimization of New Hybrid Stand-alone Renewable Energy System Considering a Reliability Index. IEEE

Garcia,R. S dan Weisser, D. (2006). A Wind-Diesel System with Hydrogen Storage Joint Optimization of Design and Dispatch. Renewable energy, 31 (14) : 2296-2320.

Hakimi, S.M and S.M. Moghaddas-Tafreshi. (2009). Optimal Sizing of a Stand-alone Hybrid Power System via Particle Swarm Optimization for Kahnouj area in south-east of Iran. Renewable Energy 34: 1855-1862.

K. M. Iromi Udumbara Ranaweera. (2013). Techno-Economic Optimum Sizing of Hybrid Renewable Energy System -Rural Electrification In Srilanka. Master Thesis, University of Agder, Grimstad, Norway, June.

Nowdeh, S. A., Ghahnavieh, A. A., and Khanabdal, S. (2010). PV/FC/Wind Hybrid System Optimal Sizing Using PSO Modified Algorithm. Buletinul Institutului Politehnic Din IASI.

Penangsang, O., Abdillah,M.,Wibowo,RS.,Soeprijanto,A. (2013). Optimal Design of Photovoltaic-Battery Systems Using Interval Type-2 Fuzzy Adaptive Genetic Algorithm. Scientific Research. 5:50-55.

Suryoatmojo, H. (2010). Artificial Intelligence Based Optimal Configuration of Hybrid Power Generation System. Dissertation Doctor of Philosophy in Department of Computer Science and Electrical Engineering. 
Optimal Design of Reneweble Energy Sytem for Tourism Destination ParangtritisUsing Genetic Algorithm

Tolooi, Z., Zayandehroodi,H., and Khajehzadeh,A. (2014). Novel Approach for Optimal Sizing of Stand-alone Hybrid Photovoltaic/Wind Systems Using Evolutionary Algorithms. ACSIJ Advances in Computer Science: an International Journal 3, Issue 6: 12.

Yang, H., Zhou,W.,Lu,L., and Fang,Z. (2008). Optimal Sizing Method for Stand-alone Hybrid Solar-wind System with LPSP Technology by using Genetic Algorithm. Solar Energy 82 (2008) : 354-367.

Yusuf, E. (2012). Optimasi Jumlah Unit Pembangkit pada Konfigurasi Sistem Hibrid Energi Terbarukan dengan Particle Swarm Optimization. Accessed from http://hypertextbook.com/facts/2005/MichelleFung.shtml. 